DOI : https://doi.org/10.24843/JFU.2020.v09.i02.p05

pISSN: 2301-7716; eISSN: 2622-4607

Jurnal Farmasi Udayana, Vol 9, No 2, Tahun 2020, 100-109

\title{
Identifikasi Komponen Volatile Kulit Ari Biji Kopi (Coffea robusta) Guna Optimalisasi Kebermanfaatan
}

\author{
Nugraha, I. M. A. D. P. ${ }^{1}$, Prayascita, P. W. ${ }^{1}$, Dwidhananta, I. M. S. ${ }^{1}$, Putra, I. P. A. M. ${ }^{1}$, Cahyani, \\ N. K. N. ${ }^{1}$, Samirana, P. O. ${ }^{1}$ \\ Program Studi Farmasi Fakultas Matematika dan Ilmu Pengetahuan Alam Universitas Udayana, \\ Jalan Kampus Unud-Jimbaran, Jimbaran-Bali, Indonesia 80364 \\ E-mail: oka samirana@unud.ac.id \\ Riwayat artikel: Dikirim: 08/08/2020; Diterima: 17/11/2020, Diterbitkan: 27/12/2020
}

\begin{abstract}
Robusta coffee (Coffea robusta) not only traded as ready-to-drink or ready-to-use products, but one of them as a product absorbing unpleasant odor. In order to produce a permanent and high quality product that absorbs unpleasant odors and natural fragrances, it's necessary to establish standards marker consisting of volatile components to produce sustainable products with constantly quality. Therefore, the aim of research is to find marker compounds from husk of robusta coffee beans which able to become the quality standards for raw material samples. This research method was preceded by maked viscous extract of coffee beans husk with methanol as solvent. The methanol extract of robusta coffee bean husk was then analyzed by GC-MS. The identification of each molecular fragment peak obtained from GC-MS was compared with a data source of WILEY7.LIB to predict the volatile components in the sample. The analysis showed that the robusta coffee bean husk extract contained Trans-Caryophyllene, Germacrene D, $\alpha$-farnesene, Caffeine, Hexadecanoic acid (Methyl ester) and Hexadecanoic acid (Ethyl ester). The volatile components can be used as marker in an effort to Quality Control (QC) odor absorbent products based on the husk of robusta coffee beans (Coffea robusta), so that a steady quality product is produced.
\end{abstract}

Keywords: Coffea robusta Husk, Volatile Component, Quality Control

\begin{abstract}
ABSTRAK
Kopi robusta (Coffea robusta) tak hanya diperjualbelikan sebagai produk siap minum ataupun siap olah, melainkan salah satunya sebagai produk penyerap bau tak sedap. Guna menghasilkan suatu produk absorbent bau tidak sedap serta pengharum natural yang ajek serta berkualitas, perlu adanya penetapan standar marker berupa komponen volatile sehingga menghasilkan produk berkesinambungan dengan kualitas tetap. Maka dari itu, penelitian ini bertujuan untuk mencari senyawa marker (penanda) dari kulit ari biji kopi robusta yang mampu menjadi standar kualitas senyawa yang dicari untuk sampel bahan baku. Metode penelitian ini didahului dengan pembuatan ekstrak kental kulit ari biji kopi robusta dengan pelarut metanol. Ekstrak metanol kulit ari biji kopi robusta selanjutnya dianalisis dengan GC-MS. Identifikasi masing-masing puncak fragmen molekul yang diperoleh dari GC-MS dibandingkan dengan sumber data berupa WILEY7.LIB untuk memprediksi komponen volatile dalam sampel. Hasil analisis menunjukkan ekstrak kulit ari biji kopi robusta mengandung Trans-Caryophyllene, Germacrene D, $\alpha$-farnesene, Caffeine, Hexadecanoic acid (Methyl ester) dan Hexadecanoic acid (Ethyl ester). Komponen volatile tersebut mampu digunakan sebagai marker (penanda) dalam upaya Quality Control (QC) produk absorbent (penyerap bau) berbahan dasar kulit ari biji kopi robusta, sehingga dihasilkan produk ajek dengan kualitas yang terjaga.
\end{abstract}

Kata kunci: Kulit Ari Coffea robusta, Komponen Volatile, Quality Control 
DOI : https://doi.org/10.24843/JFU.2020.v09.i02.p05

pISSN: 2301-7716; eISSN: 2622-4607

Jurnal Farmasi Udayana, Vol 9, No 2, Tahun 2020, 100-109

\section{PENDAHULUAN}

Kopi robusta (Coffea robusta) asal Indonesia menjadi salah satu komoditas ekspor utama di pasar internasional, yang terlihat dengan peningkatan konsumsi kopi dunia sebesar 8,47\% selama 2011-2016. Indonesia menempati urutan ke-empat di antara eksportir kopi utama dunia setelah Brasil, Vietnam dan Kolombia. Kopi robusta menjadi produk ekspor utama yang dihasilkan Indonesia, dengan persentase sebesar $74 \%$ dan $26 \%$ sisanya merupakan komoditi kopi arabika [1]. Di pasar internasional, komoditas kopi robusta tak hanya diperjualbelikan sebagai produk siap minum ataupun biji kopi siap olah, melainkan berbagai produk lain dengan kegunaan beragam. Salah satu kegunaan menarik yang dimiliki kopi robusta yaitu kemampuan penyerapan bau tak sedap [2].

Komponen yang terkandung pada biji kopi robusta (C. robusta) memiliki kemampuan dalam menyerap bau tidak sedap yang ada di sekitarnya. Bau tidak sedap akan memberikan dampak buruk terhadap indra penciuman, salah satu dampaknya adalah penciuman terganggu dan bersifat menyesakkan. Kemampuan biji kopi robusta sebagai penyerap bau tak sedap (absorbent) berkaitan dengan kandungan nitrogen yang mampu meningkatkan kemampuan karbon mengeliminasi bau tidak sedap. Aroma natural yang dihasilkan utamanya pada hasil sangrai mampu menjadi pengharum natural yang aman bagi manusia [2].

Komponen dalam biji kopi robusta (C. robusta) yang juga memiliki kemampuan penyerap bau tak sedap dan aroma natural yaitu kulit ari biji kopi. Komponen ini dihasilkan pada proses produksi biji kopi robusta utamanya proses sangrai. Kulit ari biji kopi tergolong produk buangan yang seiring berjalannya waktu produksi akan kian meningkat jumlahnya [3]. Sebagian kecil dari kulit ari biji kopi robusta di masyarakat dimanfaatkan sebagai bahan baku dalam produksi bahan bakar, pendukung fermentasi pada berbagai produk, serta sebagai pupuk [3]. Faktanya, komponen kulit ari biji kopi robusta berpotensi digunakan sebagai substitusi biji kopi robusta dalam produk absorbent sekaligus pengharum natural. Keseluruhan komponen biji kopi robusta termasuk kulit ari biji kopi memiliki komposisi senyawa kimia yang kompleks, yang terdiri atas komponen volatile dan non-volatile yang berperan penting dalam cita rasa kopi, kualitas dan efek pada kesehatan [4][5].

Guna menghasilkan suatu produk absorbent bau tidak sedap serta pengharum natural yang ajek serta berkualitas, perlu adanya suatu penetapan standar mutu berupa senyawa marker (penanda) berupa komponen volatile sehingga mampu menghasilkan produk secara berkesinambungan dengan kualitas tetap. Dalam produksi produk absorbent bau tidak sedap serta pengharum natrual, aroma sebagai indikator sensorik memegang peran kunci dalam mengevaluasi kualitas produk serta sebagai marker dari produk tersebut. Dari sudut pandang industri, prosedur yang efisien diperlukan untuk mengontrol kualitas dari produk yang dihasilkan [24]. Oleh karena itu, sangat penting untuk mengeksplorasi keberadaan senyawa dengan aroma khas pada produk selama proses produksi.

Berbagai metode telah dikembangkan dalam eksplorasi keberadaan senyawa marker dalam bahan baku ataupun produk di pasaran. Salah satu metode terdepan serta tergolong sebagai "gold standard" yang dikembangkan dalam penentuan marker berupa komponen volatile dalam produk yaitu metode GCMS [25]. Pemisahan dengan metode GC- 
DOI : https://doi.org/10.24843/JFU.2020.v09.i02.p05

pISSN: 2301-7716; eISSN: 2622-4607

Jurnal Farmasi Udayana, Vol 9, No 2, Tahun 2020, 100-109

MS didasarkan pada titik didih dan afinitas dengan kolom. GC-MS umumnya merupakan metode pilihan karena pengoperasian mudah, cepat, resolusi pemisahan yang baik, sensitivitas, dan reprodusibilitas yang tinggi. Melalui GCMS, mampu memberikan informasi terkait berat molekul dan prediksi komponen volatile di dalam sampel.

Maka dari itu, penelitian ini bertujuan mencari senyawa marker (penanda) dari kulit ari biji kopi robusta ( $C$. robusta) yang mampu menjadi standar kualitas senyawa yang dicari untuk bahan baku produk absorbent dengan metode GC-MS. Kedepannya, senyawa marker (penanda) akan mampu digunakan oleh berbagai produsen yang menggunakan kulit ari biji kopi robusta sebagai bahan baku produk absorbent sekaligus pengharum natural sebagai bentuk quality control produk yang dihasilkan [6]. Komponen volatile yang ditemukan melalui GC-MS tergolong sebagai prediksi komponen dan ke depannya akan dipelajari lebih lanjut.

\section{BAHAN DAN METODE}

\subsection{Bahan dan Alat}

Bahan-bahan yang digunakan dalam identifikasi komponen volatile pada kulit ari biji kopi yaitu kulit ari biji kopi robusta (Coffea robusta) dan metanol. Kulit ari biji kopi robusta diperoleh dari sentra pengolahan biji kopi robusta di Desa Batungsel, Kecamatan Pupuan, Kabupaten Tabanan, Bali.

Alat yang digunakan dalam identifikasi komponen volatile pada kulit ari biji kopi robusta yaitu timbangan (AND FX500i), toples kaca, alat-alat gelas (Iwaki Pyrex), kertas saring, plastic wrap, cawan porselen (Iwaki Pyrex), oven (Binder ED 53), instrumen sonikator (Branson 1510) dan instrumen GC-MS (QP 2010 Ultra).

\subsection{Metode}

2.2.1 Ekstraksi Komponen Volatile dari Kulit Ari Biji Kopi Robusta (Coffea robusta)

10 gram kulit ari biji kopi robusta $(C$. robusta) hasil sangrai ditimbang dan dimaserasi dengan $100 \mathrm{~mL}$ metanol dalam wadah toples kaca terlindung cahaya. Wadah ditutup dan didiamkan selama 5 hari sambil diaduk berulang setiap 1 hari sekali. Ekstrak disaring setelah 5 hari dan diperas. Ampas ditambahkan $25 \mathrm{~mL}$ metanol, diaduk dan diremaserasi selama 2 hari, serta disaring [7]. Ekstrak yang diperoleh diuapkan pada oven dalam wadah cawan porselen hingga diperoleh ekstrak kental, serta ditimbang bobot ekstrak kental.

\subsubsection{Analisis Komponen Volatile dengan Metode GC-MS}

Ekstrak kental dari kulit ari biji kopi robusta (Coffea robusta) sebanyak $500 \mathrm{mg}$ dilarutkan ke dalam $80 \mathrm{~mL}$ metanol dan disonikasi selama 15 menit. Larutan tersebut diinjeksikan ke dalam instrumen GC-MS sebanyak $1 \mu \mathrm{L}$. Sistem GC-MS yang digunakan yaitu dengan laju alir pada kolom $1,18 \mathrm{~mL} / \mathrm{menit}$, dengan suhu injeksi $80^{\circ} \mathrm{C}$ dan ditahan selama 2 menit. Suhu ditingkatkan sebesar $10^{\circ} \mathrm{C} /$ menit selama 10 menit hingga mencapai suhu $270^{\circ} \mathrm{C}$. Split ratio yang digunakan sebesar 100. Mode scan yang dipergunakan dalam analisis komponen volatile tergolong mode full scan, dengan rentang ion 35 hingga $500 \mathrm{~m} / \mathrm{z}$. Data masing-masing puncak fragmen molekul yang diperoleh dari GC-MS kemudian dibandingkan dengan sumber data berupa WILEY7.LIB [8].

\section{HASIL}

Hasil yang diperoleh dari proses ekstraksi yaitu didapatkan ekstrak kental berwarna coklat kehitaman yang diduga 
DOI : https://doi.org/10.24843/JFU.2020.v09.i02.p05

pISSN: 2301-7716; eISSN: 2622-4607

Jurnal Farmasi Udayana, Vol 9, No 2, Tahun 2020, 100-109

memiliki komponen volatile. Berdasarkan pustaka, kulit ari kopi robusta (C. robusta) yang tumbuh di daerah Desa Batungsel, Kecamatan Pupuan, Kabupaten Tabanan, Bali mengandung beberapa komponen volatile yang sama dengan kopi robusta $(C$. robusta) yang tumbuh di daerah Jawa Barat pada penelitian Hafsah et al (2020) [23]. Komponen-komponen volatile dan nonvolatile yang terdeteksi pada GC-MS terdiri atas sepuluh senyawa dengan Rt (retention time) serta \% area bervariasi. Komponenkomponen yang terdeteksi pada GC-MS disajikan pada Tabel 1 .

Tabel 1. Komposisi Kimia Ekstrak Metanol Kulit Ari Biji Kopi Robusta (Coffea robusta) setelah Dianalisis dengan GC-MS

\begin{tabular}{clcc}
\hline No & \multicolumn{1}{c}{ Nama Senyawa } & RT & Area (\%) \\
\hline 1 & Trans-Caryophyllene & 10.509 & 4.56 \\
2 & Germacrene D & 11.295 & 3.59 \\
3 & Alpha-Farnesene & 11.465 & 4.35 \\
4 & Pentan-1,3-Dioldiisobutyrate & 12.498 & 10.22 \\
5 & Benzyl Benzoate & 14.674 & 8.99 \\
6 & Caffeine & 15.459 & 40.17 \\
7 & Hexadecanoic acid (methyl ester) & 16.196 & 11.48 \\
8 & Hexadecanoic acid (ethyl ester) & 16.873 & 7.69 \\
9 & Octadecadienoic acid & 17.854 & 3.13 \\
10 & Silikonfett SE30 (Grevels) & 22.175 & 5.81 \\
\hline
\end{tabular}

* RT $=$ Retention Time (Waktu Retensi)

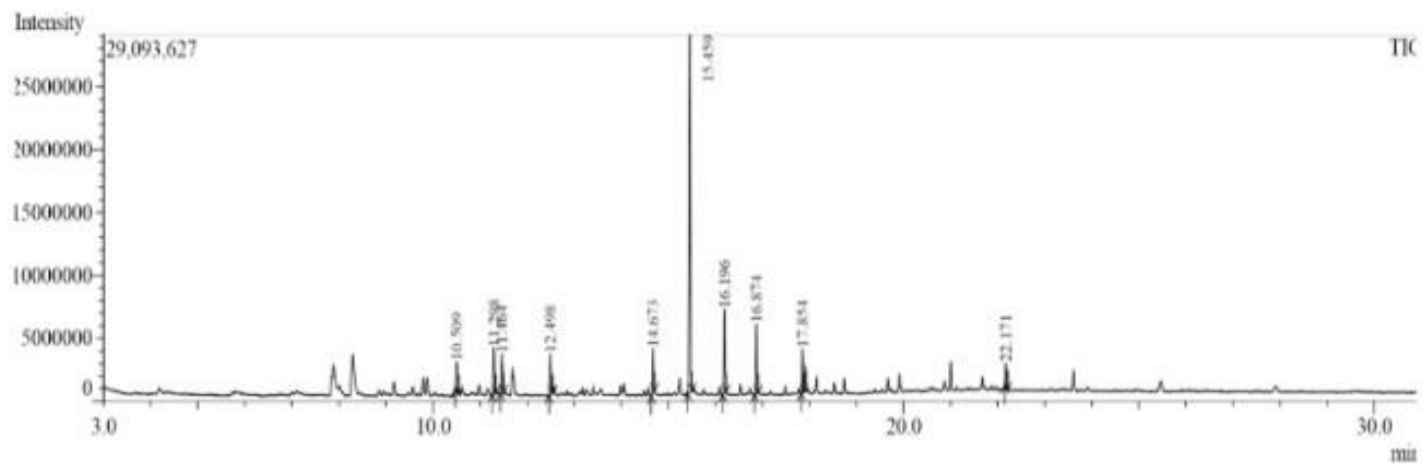

Gambar 1. Kromatogram GC-MS dari Ekstrak Metanol Kulit Ari Biji Kopi Robusta (Coffea robusta)

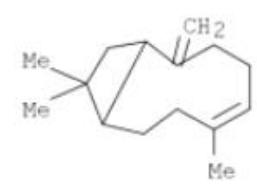

(1)

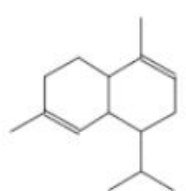

(2)

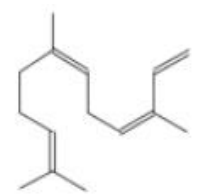

(3)

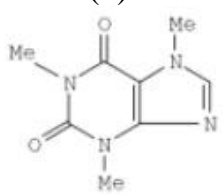

(6)

(4)

(5)

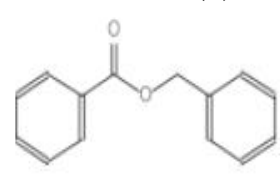

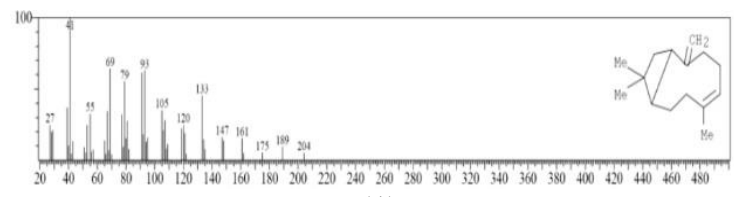

(1)

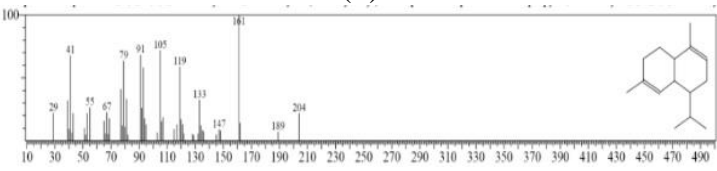

(2)

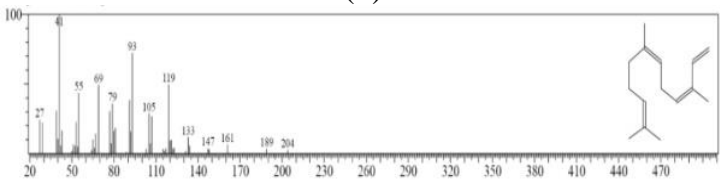

(3) 
DOI : https://doi.org/10.24843/JFU.2020.v09.i02.p05

pISSN: 2301-7716; eISSN: 2622-4607

Jurnal Farmasi Udayana, Vol 9, No 2, Tahun 2020, 100-109

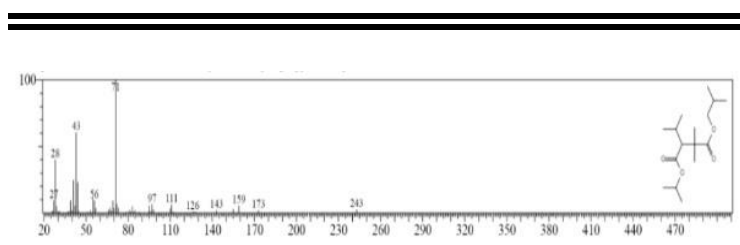

(4)

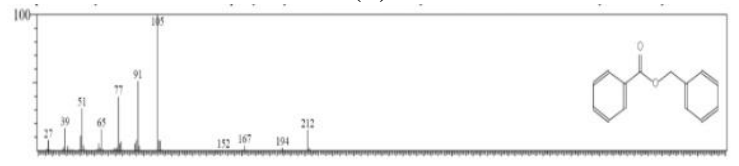

(5)

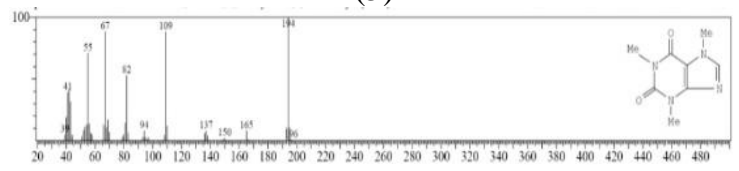

(6)

Gambar 3. Mass Spectra GC-MS dari Beberapa Senyawa Ekstrak Metanol Kulit Ari Biji Kopi Robusta (Coffea robusta) Hasil Perbandingan dengan Sumber Data WILEY7.LIB

\section{PEMBAHASAN}

GC-MS yang digunakan dalam analisis awal kandungan kimia dari ekstrak kulit ari biji kopi robusta (Coffea robusta) memiliki kolom kapiler Rtx-5MS (30 x 0,25 mm, I.d.) yang dilapisi dengan $0,25 \mu \mathrm{m}$ film yang terbuat dari $5 \%$ fenil metal silokan dan digunakan pada proses pemisahan. Kolom diatur pada suhu $80^{\circ} \mathrm{C}$. Suhu injeksi yang digunakan adalah $250^{\circ} \mathrm{C}$ dengan mode splitless dengan split ratio 100 . Waktu sampling yang digunakan selama 1 menit dengan kecepatan alir linear. Tekanan yang digunakan adalah $79.5 \mathrm{kPa}$. Suhu antarmuka diatur pada $250^{\circ} \mathrm{C}$ dan sampel yang diinjeksikan sebanyak $1 \mu \mathrm{L}$. Spektrum massa tercatat dengan rentang ion pemindaian sebesar $35-500 \mathrm{~m} / \mathrm{z}$ dengan kecepatan pemindaian $1666 \mathrm{u} / \mathrm{s}$.

Identifikasi dari masing-masing puncak yang diperoleh dari metode GC-MS dilaksanakan dengan membandingkan hasil puncak yang diperoleh dengan sumber data berupa WILEY7.LIB [9]. GC-MS memberikan informasi berat molekul dan prediksi struktur molekul. GC-MS memberikan puncak berupa fragmen- fragmen molekul yang dicirikan oleh rasio massa terhadap muatan $(\mathrm{m} / \mathrm{z})$ [26]. Nilai $\mathrm{m} / \mathrm{z}$ yang diperoleh selanjutnya dibandingkan dengan sumber data pada komputer. Kesamaan nilai $\mathrm{m} / \mathrm{z}$ yang diperoleh dengan yang tersedia pada sumber data akan mengindikasikan prediksi komponen volatile dalam sampel.

Hasil pengamatan yang diperoleh pada mass spectra GC-MS, menunjukkan prediksi beberapa komponen volatile yang ditemukan dan termasuk ke dalam senyawa volatile hidrokarbon dengan konstituen teroksigenasi. Temuan tersebut senada dengan penentuan berbagai senyawa marker pada kulit ari kopi robusta (Coffea robusta) pada berbagai pustaka. Penelitian Hafsah et al (2020) menemukan adanya senyawa marker yang serupa, yaitu TransCaryophyllene dengan $\mathrm{Rt}$ sebesar 24.175 menit; Benzyl benzoate dengan Rt sebesar 7.962 menit; Caffeine dengan Rt sebesar 15.891, 15.805, 15.883, serta 15.801 menit; Hexadecanoic acid (Methyl ester) dengan Rt sebesar 16.096 menit; Hexadecanoic acid (Ethyl ester) dengan Rt sebesar 22.571 dan 21.219 menit; serta Octadecadienoic acid dengan Rt sebesar 17.852 dan 17.695 menit [21]. Perbedaan Rt yang dihasilkan antara pustaka dengan penelitian ini dapat disebabkan oleh perbedaan kondisi kromatografi pada sistem GC yang berbeda, seperti laju alir, suhu yang digunakan pada kolom ataupun injektor, serta panjang kolom yang digunakan sehingga memberi pengaruh besar terhadap kesamaan nilai Rt yang dihasilkan [22]. Penggunaan split ratio dalam proses injeksi yang terlalu rendah ataupun laju alir pada kolom terlalu tinggi dapat pula menyebabkan proses pemisahan tidak berjalan secara efisien sehingga nilai Rt yang diperoleh akan berbeda pada satu senyawa yang sama.

Perbedaan nilai Rt yang diperoleh dengan pustaka yang ada pada senyawa yang 
DOI : https://doi.org/10.24843/JFU.2020.v09.i02.p05

pISSN: 2301-7716; eISSN: 2622-4607

Jurnal Farmasi Udayana, Vol 9, No 2, Tahun 2020, 100-109

sama dapat pula disebabkan oleh perbedaan kondisi iklim yang dimiliki pada masingmasing daerah tempat pengambilan sampel. Faktor iklim seperti perbedaan jumlah karbon dioksida $\left(\mathrm{CO}_{2}\right)$ di udara serta adanya peningkatan suhu memiliki pengaruh besar terhadap kandungan metabolit sekunder yang dihasilkan suatu tumbuhan [23]. Kandungan $\mathrm{CO}_{2}$ yang tinggi dapat meningkatkan sintesis metabolit sekunder berupa senyawa fenolik namun akan menurunkan sintesis metabolit sekunder berupa terpenoid. Suhu udara yang meningkat akan memiliki efek berlawanan, yaitu mampu menurunkan sintesis senyawa fenolik namun meningkatkan sintesis senyawa terpenoid. Perbedaan iklim akan menghasilkan perbedaan unsur hara yang diperoleh suatu tumbuhan utamanya yang diserap dari dalam tanah, sehingga akan berdampak dalam proses adaptasi dari sintesis metabolit sekunder suatu tumbuhan melalui jalur metabolisme tertentu. Produk metabolit yang dihasilkan setelah mengalami adaptasi akan memiliki karakteristik yang sedikit berbeda, seperti sifat fisiko kimia yang dimiliki, sehingga dapat berdampak pada hasil Rt yang dihasilkan. Proses adaptasi dari sintesis metabolit sekunder pada tumbuhan mampu menghasilkan metabolit sekunder yang berbeda, sehingga mampu digunakan sebagai senyawa marker dari suatu tumbuhan di daerah tersebut.

Trans-Caryophyllene masuk ke dalam sesquiterpene bi-cyclic yang secara aktif diproduksi oleh tumbuhan untuk merespon ancaman dari hewan herbivora [10]. Senyawa ini memiliki efek klinis langsung pada otot polos saluran napas. TransCaryophyllene memiliki aktivitas antispasmodik pada otot polos trakea [11]. Hal ini disebabkan adanya blockade pada kanal $\mathrm{Ca}^{2+}$. Efek tersebut akan mampu mencegah dan mengobati gejala asma, serta menimbulkan sensasi rileks bagi penghirupnya. Selain itu, aktivitas antimikroba dan analgesik dimiliki pula oleh trans-Caryophyllene.

Germacrene $D$ tergolong senyawa sesquiterpene dan termasuk dalam komposisi utama pada essential oil yang dimiliki oleh tumbuhan. Germacrene $D$ secara klinis terbukti mampu memiliki aktivitas antikanker yang efektif dan antimikroba kuat [12]. Selain itu, Germacrene $D$ tergolong antioksidan yang kuat dikarenakan struktur kimia yang memiliki cyclic methylene ekstra [13].

$\alpha$-farnesene tergolong terpenoid hidrokarbon (campuran monoterpenoid dan sesquiterpenoid). Senyawa ini mampu digunakan sebagai bahan baku dalam bahan bakar diesel dan jet [14]. Dengan bau yang khas dan tajam, maka $\alpha$-farnesene berpotensi sebagai alarm pheromone guna membasmi hama kutu.

\section{Caffeine (1,3,7-trimethylxanthine)} merupakan bahan aktif utama dalam biji kopi, termasuk dalam golongan alkaloid methylxanthine yang bertindak sebagai antagonis dari reseptor adenosin A1, A2A, dan A2B. Methylxanthine adalah senyawa yang mampu memicu diuresis [15]. Caffeine dapat merangsang tubuh manusia untuk bekerja lebih lama [16]. Caffeine juga memberikan kontribusi pada rasa kopi.

Hexadecanoic acid (methyl ester) memiliki kemampuan untuk menurunkan kolesterol dalam darah [17]. Hexadecanoic acid (methyl ester) bekerja menghambat enzim Siklooksigenase (COX) II dan menghasilkan aksi antiinflamasi selektif. Hexadecanoic acid (methyl ester) juga memiliki aktivitas sebagai antioksidan.

Hexadecanoic acid (Ethyl ester), dikenal juga dengan nama asam palmitat etil ester. Senyawa ini dapat dimanfaatkan sebagai perasa, wewangian, lubrikan, bahan 
DOI : https://doi.org/10.24843/JFU.2020.v09.i02.p05

pISSN: 2301-7716; eISSN: 2622-4607

Jurnal Farmasi Udayana, Vol 9, No 2, Tahun 2020, 100-109

tambahan kosmetika, memiliki aktivitas antibakteri serta hiperkolesterolemia [18].

Keenam senyawa di atas memiliki peran dalam proses penyerapan bau tidak sedap. Faktanya, komponen pada biji kopi, salah satunya kulit ari biji kopi robusta $(C$. robusta) memiliki kemiripan dengan sifat karbon aktif yang telah dipercaya sebagai absorben, sehingga mampu digunakan dalam menyerap bau tidak sedap di sekitarnya [19]. Empat atom nitrogen yang ditemukan pada struktur senyawa Caffeine memiliki kemampuan dalam menginduksi senyawa karbon dalam rangka mengeliminasi bau tidak sedap [2]. Kandungan senyawa Caffeine dalam kopi robusta $(C$. robusta) jauh lebih tinggi dibandingkan senyawa lainnya yang berdampak langsung pada kemampuannya menginduksi senyawa karbon.

Komponen volatile yang ditemukan pada kulit ari kopi robusta ( $C$. robusta) tergolong sebagai senyawa hidrokarbon yang didominasi tersusun atas atom karbon dengan berbagai konformasi struktur molekul berbeda. Mekanisme yang dimiliki dari atom karbon dalam mengeliminasi bau tidak sedap didasarkan pada adsorpsi fisik dari fase gas ke fase padat yaitu kulit ari kopi robusta ( $C$. robusta). Mekanisme adsorpsi fisik secara efektif terjadi pada kisaran suhu rendah (5 hingga $30^{\circ} \mathrm{C}$ ), dibandingkan dengan proses adsorpsi kimia yang efektif terjadi pada kisaran suhu tinggi (45 hingga $80^{\circ} \mathrm{C}$ ) [20]. Senyawa karbon memiliki kapasitas adsorpsi yang sangat baik (>20\% berat absorbat per berat kulit ari kopi).

Senyawa polutan dalam fase gas akan berdifusi melalui struktur berpori yang terbentuk dari konformasi atom karbon ke pori-pori yang lebih kecil yang diatur oleh energi potensial dari gaya tarik Van der Waals antara permukaan molekul absorben dan absorbat [20]. Tingkat difusi akan bergantung pada ukuran molekul dan struktur pori-pori yang terbentuk dari konformasi atom karbon pada kulit ari biji kopi robusta ( $C$. robusta). Proses difusi akan berlanjut hingga molekul polutan tidak lagi memiliki energi yang cukup untuk melepaskan diri dari ikatan Van der Waals yang menahannya menuju dinding pori-pori.

Beragam khasiat dan manfaat yang telah dilaporkan di atas dari masing-masing prediksi komponen volatile menunjukkan bahwa kulit ari biji kopi robusta (C. robusta) memiliki potensi yang dapat dimanfaatkan secara massal di masyarakat. Komponen volatile pada kulit ari, yaitu transCaryophyllene, Germacrene $D, \quad \alpha$ Farnesene, Caffeine, Hexadecanoic acid (methyl ester), dan Hexadecanoic acid (Ethyl ester) ditemukan sebagai komponen dominan sehingga dapat dipergunakan sebagai senyawa penanda (marker). Keberadaan senyawa marker sendiri akan dipergunakan sebagai Quality Control (QC) pada berbagai produk absorbent (penyerap bau) serta pengharum natural berbahan dasar kulit ari biji kopi robusta ( $C$. robusta), sehingga dihasilkan produk yang ajek [6]. Komponen volatile pada kulit ari tersebut berpotensi pula untuk diolah menjadi fragrances, flavouring agent, ataupun produk farmasetikal. Beragam potensi yang dimiliki dari kulit ari biji kopi robusta ( $C$. robusta) sendiri akan menekan jumlah limbah yang dihasilkan akibat produk buangan hasil proses sangrai biji kopi robusta (kulit ari biji kopi) di berbagai daerah. Perlu diingat kembali bahwa hasil identifikasi yang diperoleh dengan metode GC-MS merupakan prediksi berbagai komponen volatile yang terkandung dalam kulit ari biji kopi robusta (C. robusta). Dalam rangka memperoleh informasi struktur serta komponen volatile yang akurat dalam sampel, diperlukan adanya analisis lebih lanjut dengan memanfaatkan metode H-NMR dan C-NMR. Setelah diperoleh 
DOI : https://doi.org/10.24843/JFU.2020.v09.i02.p05

pISSN: 2301-7716; eISSN: 2622-4607

Jurnal Farmasi Udayana, Vol 9, No 2, Tahun 2020, 100-109

informasi spesifik berkaitan struktur dan komponen volatile dalam sampel, diharapkan dapat terlaksana penelitianpenelitian mendalam terkait aktivitas dan aplikasinya dalam sebuah produk untuk masyarakat.

\section{KESIMPULAN}

Prediksi komponen volatile yang terdapat dalam ekstrak kulit ari biji kopi robusta $(C$. robusta) melalui metode GCMS, yaitu trans-Caryophyllene (1, 4.56\%), Germacrene D (2,3.59\%), alpha-Farnesene (3, 4.35\%), Caffeine (6, 40.17\%), Hexadecanoic acid (methyl ester) (7, $11.48 \%$ ), dan Hexadecanoic acid (Ethyl ester) $(8,7.69 \%)$ yang dapat digunakan dan dikembangkan secara massal oleh masyarakat. Prediksi komponen senyawa volatile tersebut dapat digunakan sebagai marker (penanda) dalam upaya Quality Control (QC) produk absorbent (penyerap bau) berbahan dasar kulit ari biji kopi robusta $(C$. robusta), sehingga dihasilkan produk yang ajek dengan kualitas yang terjaga. Perlu dilakukan adanya analisis lebih lanjut dengan memanfaatkan metode H-NMR dan C-NMR guna memperoleh struktur dan komponen volatile yang akurat.

\section{UCAPAN TERIMAKASIH}

Penulis mengucapkan terima kasih kepada Direktorat Pendidikan Tinggi Kementerian Pendidikan dan Kebudayaan Republik Indonesia dan Rektor Universitas Udayana melalui Program Studi Farmasi Fakultas Matematika dan Ilmu Pengetahuan Alam Universitas Udayana yang telah memfasilitasi dan mendanai penelitian ini, serta Laboran Laboratorium Analisis Program Studi Farmasi Universitas Udayana yang menjadi wahana dalam penelitian kami.

\section{DAFTAR PUSTAKA}

[1] N. Rostana, R. Nurmalina, R. Winandi and A. Rifin, "Dynamics of Indonesian Robusta Coffee Competition among Major Competitor Countries" Jurnal Tanaman Industri dan Penyegar, vol. 5, no. 1, p. 1-10, 2018.

[2] F. Shemekite, M. G. Brandon, I. H. F. Whittle, B. Praehauser, H. Insam and F. Assefa, "Coffe Husk Composting: An Investigation of The Process Using Molecular and Non-molecular Tools" Waste Management, vol. 34, no. 3, p. 642-652, 2014.

[3] H. M. A. Yousef and M. Amina, "Essential Oil of Coffea arabica L. Husks: A Brilliant Source of Antimicorbal and Antioxidant Agents" Biomedical Research, vol. 29, no. 1, p. 174-180, 2018.

[4] A. Yashin, Y. Yashin, X. Xia and B. Nemzer, "Chromatographic Methods for Coffee Analysis: A Review" Journal of Food Research, vol. 6, no. 4, 2017.

[5] R. C. L. Affonso, A. P. L. Voytena, S. Fanan, H. Pitz, D. S. Coelho, A. L. Horstmann, A. Pereira, V. G. Uarrota, M. C. Hillmann, L. A. C. Varela, R. M. R. Valle and M. Maraschin, "Phytochemical Composition, Antioxidant Activity, and the Effect of the Aqueous Extract of Coffee (Coffea arabica L.) Bean Residual Press Cake on the Skin Wound Healing" Oxidative Medicine and Cellular Longevity, vol. 2016, no. 1, 2016.

[6] W. Setyaningsih, T. Majchrzak, T. Dymerski, J. Namiesnik and M. Palma, "Key-Marker Volatile Compounds in Aromatic Rice (Oryza sativa) Grains: An HS-SPME Extraction Method Combined with GC-TOFMS" Molecules, vol. 24, no. 1, p 1-15, 2019. 
DOI : https://doi.org/10.24843/JFU.2020.v09.i02.p05

pISSN: 2301-7716; eISSN: 2622-4607

Jurnal Farmasi Udayana, Vol 9, No 2, Tahun 2020, 100-109

[7] M. R. Harahap, "Identifikasi Daging Buah Kopi Robusta (Coffea robusta) Berasal dari Provinsi Aceh" Elawnie: Journal of Islamic Science and Technology, vol. 3, no. 2, 2017.

[8] B. Y. K. Sruthi, B. M. Gurupadayya, V. Sairam and T. N. Kumar, "Development and Validation of GC Method for This Estimation of Eugenol in Clove Extract" International Journal of Pharmacy and Pharmaceutical Sciences, vol. 6, no. 2, 2014.

[9] E. P. Setyowati, S. U. T. Pratiwi, T. Hertiani and O. Samara, "Bioactivity of Fungi Trichoderma reesei Associated with Sponges Stylissa flabelliformis Collected from National Park West Bali, Indonesia" Journal of Biological Sciences, vol. 17 , no. 8, p. 362-368, 2017.

[10]F. Araniti, A. M. S. Moreiras, E. Grana, M. J. Reigosa and M. R. Abenavoli, "Terpenoid Trans-Caryophyllene Inhibits Weed Germination and Induces Plant Water Status Alteration and Oxidative Damage in Adult Arrabidopsis" Plant Biology, vol. 19, no. 1, p. 1-11, 2016.

[11]L. P. Silva, P. V. M. Maia, T. M. N. G. Teofilo, R. Barbosa, V. M. Ceccatto, A. N. C. Souza, J. S. Cruz and J. H. L Cardoso, "Trans-Caryophyllene, a Natural Sesquiterpene, Causes Tracheal Smooth Muscle Relaxation through Blockade of Voltage-Dependent $\mathrm{Ca}^{2+}$ Channels" Molecules, vol. 2012, no. 17, p. 11965-11977, 2012.

[12]P. Sitarek, P. Rijo, C. Garcia, E. Skala, D. Kalemba, A. J. Bialas, J. Szemraj, D. Pytel, M. Toma, H. Wysokinska and T. Sliwinski, "Antibacterial, AntiInflammatory, Antioxidant, and Antiproliferative Properties of Essential Oils from Hairy and Normal Roots of Leonurus sibiricus L. and Their
Chemical Composition" Oxidative Medicine and Cellular Longevity, vol. 2017, no. 1, p. 1-12, 2017.

[13] N. S. Carneiro, C. C. F. Alves, J. M. Alves, M. B. Egea, C. H. G. Martins, T. S. Silva, L. C. Bretanha, M. P. Balleste, G. A. Micke, E. V. Silveira and M. L. D. Miranda, "Chemical Composition, Antioxidant and Antibacterial Activities of Essential Oils from Leaves and Flowers of Eugenia klotzschiana Berg (Myrtaceae)" Anais da Academia Brasileria de Ciencias, vol. 89, no. 3, p. 1907-1915, 2017.

[14] N. N. Rusdi, H. H. Goh, S. Sabri, A. B. Ramzi, N. M. Noor and S. N. Baharum, "Functional Characterisation of New Sesquiterpene Synthase from the Malaysian Herbal Plant, Polygonum Minus" Molecules, vol. 2018, no. 23, p. 1-15, 2018.

[15] S. Wonorahardjo, N. Yuniawati, A.D.P. Molo, H.O. Rusdi and H. Purnomo, "Different Chemical Compound Profiles of Indonesian Coffee Beans as Studied Chromatography / Mass Spectrometry" IOP Conf. Series: Earth and Environmental Science, vol. 276, p. 1-8, 2019.

[16]F. Burdan, "Pharmacology of Caffeine : The Main Active Compound of Coffee" Coffee in Health and Disease Prevention, vol. 90, no.5, p. 823-829, 2015.

[17] G. Belakhdar, A. Benjouad, and E.H. Abdennebi, "Determination of Some Bioactive Chemical Constituents from Thesium humile Vahl" J. Mater. Environ. Sci, vol.6, no.10, p. 27782783, 2015.

[18] V.A. Gideon, "GC-MS Analysis of Phytochemical Components of Pseudoglochidion anamalayanum Gamble: An Endangered Medicinal Tree" Asian Journal of Plant Science 
DOI : https://doi.org/10.24843/JFU.2020.v09.i02.p05

pISSN: 2301-7716; eISSN: 2622-4607

Jurnal Farmasi Udayana, Vol 9, No 2, Tahun 2020, 100-109

and Research, vol.5, no.12, p. 36-41, 2015.

[19] A. B. Rivanta, dan R. Febriyanti, "Pengaruh Kombinasi Ekstrak Biji Kopi dan Rimpang Jahe Terhadap Sifat Fisik Sediaan Foot Sanitizer Spray" Jurnal Para Pemikir, vol. 7, no. 2, p. 247-251, 2018.

[20] N. L. Minh, E. C. Sivret, A. Shammay, and R. M. Stuetz, "Factors Affecting the Adsorption of Gaseous Environmental Odors by Activated Carbon: A Critical Review" Critical Reviews in Environmental Science and Technology, vol. 48, no. 4, p. 1-35, 2018.

[21] H. Hafsah, I. Iriawati, and T. S. Syamsudin, "Dataset of Volatile Compounds from Flowers and Secondary Metabolites from the Skin Pulp, Green Beans, and Peaberry Green Beans of Robusta Coffee". Data in Brief, vol. 29, no. 1, p. 1-9, 2020.

[22] S. Ahuja, Chromatography and Separation Science, Fourth ed., Amsterdam: Academic Press, 2003.

[23] J. K. Holopainen, V. Virjamo, R. P. Ghimire, J. D. Blande, R. J. Tiitto, and M. Kivimaenpaa, "Climate Change Effects on Secondary Compounds of Forest Trees in the Northern Hemisphere" Frontiers in Plant Science, vol. 9, no. 1, p. 1-10, 2018.

[24] H. Zhang, H. Chen, W. Wang, W. Jiao, W. Chen, Q. Zhong, Y. H. Yun, and W. Chen, "Characterization of Volatile Profiles and Marker Substances by HS-SPME/GC-MS during the Concentration of Coconut Jam" Foods, vol. 9, no. 347, p. 1-16, 2020.

[25] D. A. Skoog, F. J. Holler, and S. R. Crouch, Principles of Instrumental Analysis, Seventh ed., USA: Cengage Learning, 2018.
[26] T. O. Nicolescu, Mass Spectrometry, First ed., London: IntechOpen, 2017. 